\title{
STUDY OF THE UTILIZATION OF RIM (REFRESH MICROORGANISM) IN SUGARCANE
}

\author{
SUDIARSO ${ }^{1 \star \otimes}$, Ririen PRIHANDARINI ${ }^{2}$ \\ ${ }^{1}$ Faculty of Agriculture, University of Brawijaya, Malang, Indonesia \\ 2 Faculty of Agriculture, Widyagama University, Malang, Indonesia \\ Email: sudiarso1105@gmail.com \\ supporting Information
}

\begin{abstract}
Sugarcane is used by its stems as the main raw material for sugar. In addition to improving soil structure, soil organic matter also supplies soil nutrients, especially Nitrogen, Phosphor and Sulfur, increases soil aggregate stability, increases groundwater holding capacity and increases soil recoverability. To overcome this problem, the use of RIM microorganism (refresh microorganism) technology in sugarcane fields needs to be done to reduce the use of chemical fertilizers which will ultimately lead to the realization of the application of organic farming systems in sugarcane cultivation. The purpose of this study was to study the effect of different dosage applications of RIM and various sources of organic matter on the growth and yield of sugarcane. This research consisted of two stages, namely in the greenhouse and in the field, namely (1) testing the growth of bud chip sugarcane seedlings using different growth media and microorganism technology (2) testing the effect of RIM applications and organic matter on the growth and yield of sugarcane. The use of RIM's Biological Agents by using Tricho derma, Sacharomyces, Bacillus, Rhizobium, Azotobacter and Pseudomonas bacteria was able to increase the growth of sugarcane buds. The combination of using RIM and manure can increase the number of leaves and the percentage of growing sugarcane.
\end{abstract}

Keywords: Beneficial microorganism, Organic Material. RIM's Biological Agent, Sugarcane.

\section{INTRODUCTION}

Sugarcane (Sacharum officinarum L.) is a plant in the Graminae family which is used by its stems as the main raw material for sugar, as well as animal feed. Along with the development of the population, Indonesia has not been able to meet the national sugar needs. This is evidenced by the decline in sugarcane productivity in 2017 which only reached 5.4 tonnes/ha compared to the 2016 projection of 7.75 tonnes/ha (Agricultural Statistics at a Glance 2018). The low productivity of sugarcane, followed by an increase in sugar consumption, makes Indonesia have to import sugar from abroad. Domestic sugar needs are mostly met from imported sugar in the form of raw sugar and crystal sugar, even in 2018 it was reported that National sugar production only reached 2.1 million tons per year, while the need for consumption and refined sugar reached 6.8 million tons.

The low sugarcane production can be seen from the on-farm side, including the low soil fertility caused by the low content of organic matter in the soil. Soil organic matter has biological, physical and chemical functions of soil which are mutually bound to one another. Soil organic matter in addition to providing nutrients for soil microbial activity, nutrients used by microorganisms are useful for accelerating their activity in order to increase the rate of decomposition of organic matter and release of nutrients (Sutanto, 2016). It was stated that that drought on the soil will result in reduced chlorophyll a,b content, the ratio of chlorophyll a,b decreases physiological activity and will reduce sugarcane plant growth and sugar productivity (Ferreira et al., 2017). Further, it was determined( that about $60 \%$ of rice fields in Java show less than $1 \%$ organic matter, meanwhile for the agricultural system to be sustainable, it must have organic matter greater than $2 \%$. Rhizhobacterium was able to increase the growth and photosynthesis of sugarcane plants (Rampazzo et al., 2018).

Dependence on chemical fertilizers causes chemical fertilizer subsidies to increase every year. The environmental burden caused by the continuous use of chemical fertilizers in high doses is increasingly closing the soil pores, so that the absorption of the soil to rain water decreases and results in frequent flooding and drought (Thierfelder et al., 2018). In addition, the continuous use of chemical fertilizers causes the soil to become hard so that crop production, especially sugar cane, is getting smaller with a low yield of sugar. To overcome this problem, the use of microorganisms in sugarcane fields needs to be done to reduce the use of chemical fertilizers which will eventually lead to the realization of the application of organic farming systems in sugarcane cultivation. Microorganism technology engineering is expected to improve soil fertility so that it will increase the production and yield of sugarcane.

The current research purposes were 1) study the effect of different application of RIM dosages and various sources of organic matter on soil fertility and sugarcane crops; 2) Studying the effect of RIM and the dosage of organic matter on the growth and yield of sugarcane. The research outputs to be achieved are: (a) publication in national or international seminar proceedings, and (b) technology package for organic sugarcane cultivation. 


\section{MATERIALS AND METHODS}

This study consisted of two stages, namely in the greenhouse and in the field, namely, 1) the growth test of bud chip sugarcane seedlings using different growing media and hygienic agents, 2) testing the effect of RIM application and organic matter on the growth and yield of sugarcane (Figures 1-4).

The first stage of research was the growth test of bud chip sugarcane seedlings using different growing media combined with different microorganism formulas. The objective of this research is to obtain an optimal growing environment for the growth of bud chip sugarcane. The experimental design used was a completely randomized design; the study was conducted in a greenhouse. Synergy test between a consortium of microorganisms between photosynthetic bacteria Sacharomyces (S), Azospirillum sp (A), Azotobacter (Z), Rhizobium (R), Pseudomonas (P), Bacillus (B) and Trichoderma sp. (T) with a comparison, the formula is F1, F2, F3, F4 and F5. Plant shoot variables observed were the percentage of shoots that grew on the pottray and time of shoot growth.

The second stage of research was a continuation of stage 1, the growth of shoots was followed by the influence of the growth of sugarcane shoots with RIM treatment combined with various kinds of organic matter and the concentration of biological agents on the growth and yield of sugarcane. The experimental design used was a randomized block design with 7 treatments on various planting media samples:

S0: control, S1: RIM 5 gr, S2: RIM 10 gr S3: RIM 20 gr, S4: manure + RIM 5 gr, S5: manure + RIM 10 gr, S6: manure + RIM 20 gr and S7: fertilizer cage. So there are 8 treatments, each treatment is repeated 3 times. There are 24 research treatments. Plant variables that are observed are plant height and number of leaves. Observation of soil fertility includes laboratory analysis of soil nutrient content before and after treatment, and soil microorganism population. The data obtained were analyzed using analysis of variance and significant difference test.

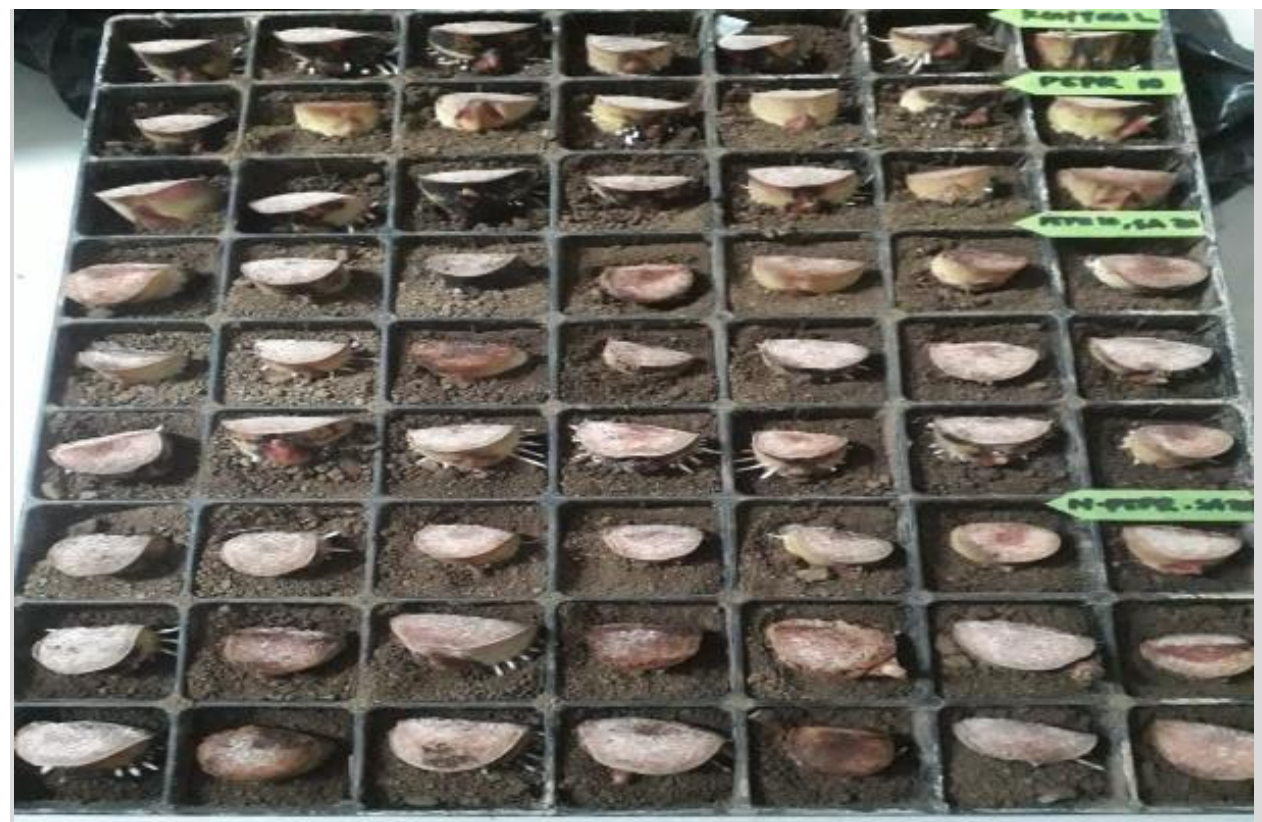

Figure 1 - Growth of bud chip sugarcane seedlings using different growing media and biological agents or various formulas.

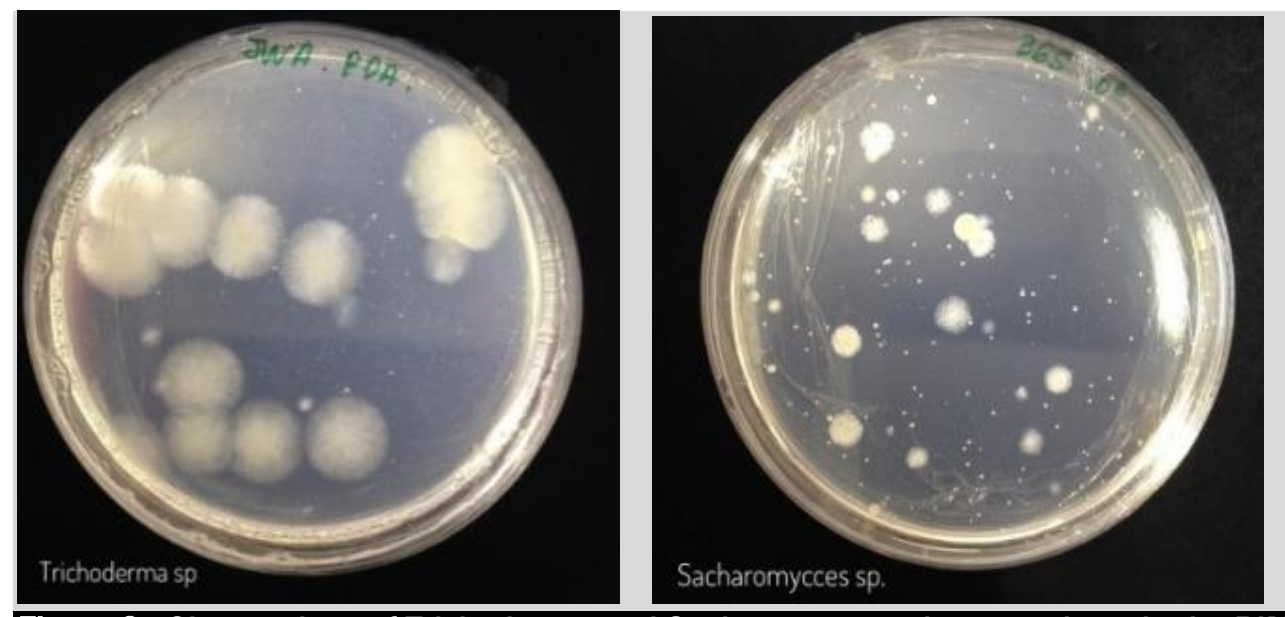

Figure 2 - Observations of Trichoderma and Sacharomyces microorganisms in the RIM formulation. 

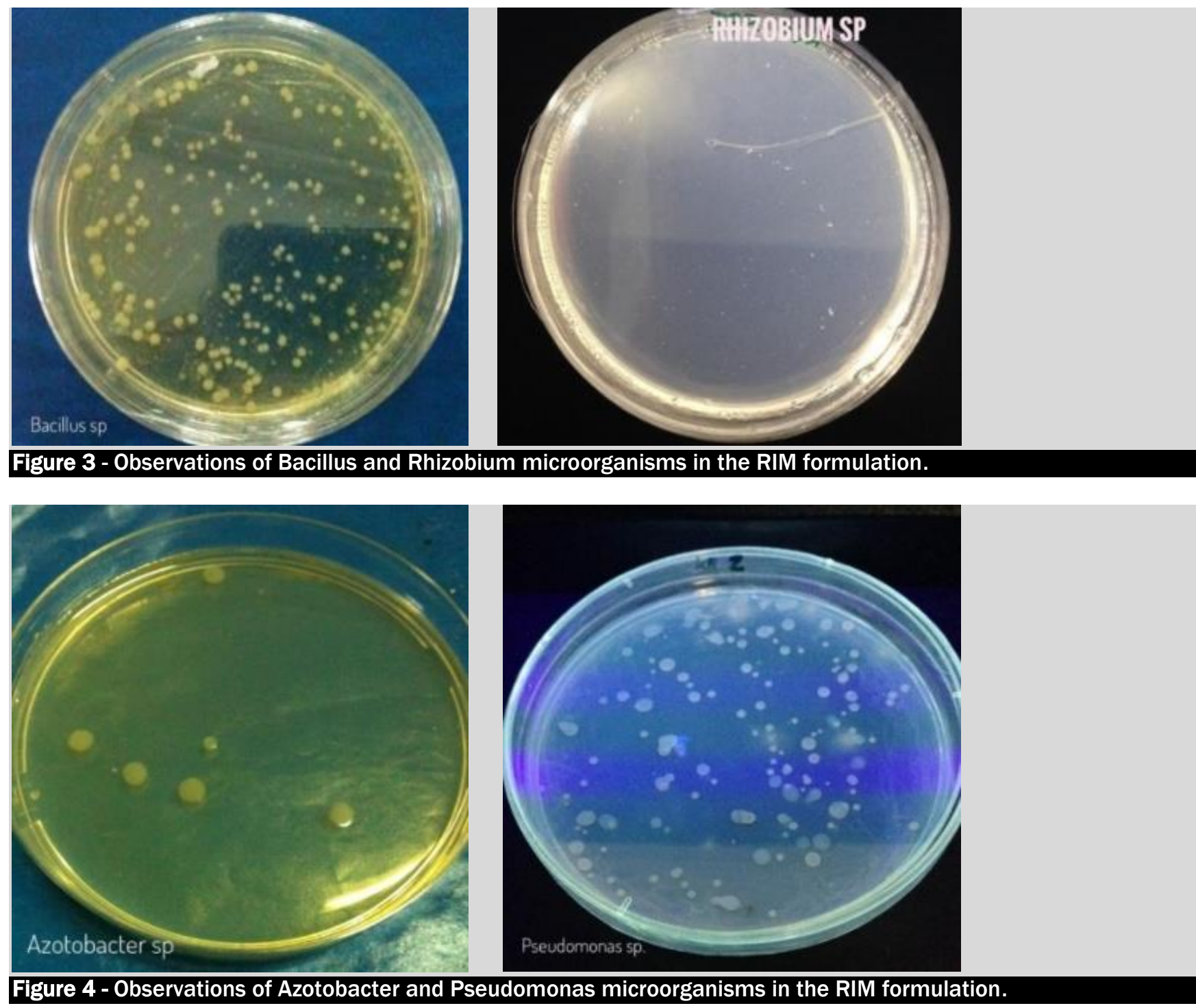

\section{RESULTS}

Bud chip cane seed growth test using different growing media and biological agents

Based on the synergy test between the microorganism consortium between the photosynthetic bacteria Sacharomyces (S), Azospirillum sp (A), Azotobacter (Z), Rhizobium (R), Pseudomonas (P), Bacillus (B) and Trichoderma sp (T) with a comparison, the formula is obtained F1, F2, F3, F4 and F5 that are used can synergize with one another. From the results of the incubation for $\mathbf{2 4}$ hours, each formula has a predominance and can be mixed and F3 is the best formula and is used in further research. Based on this test and formulation, a formula is obtained that can increase the speed of growth of sugarcane seeds and is expected to be used as biological fertilizer for sugarcane plants. However, it still needs to be studied in more detail whether the formula is correct in a soil biology laboratory then it is followed by a test of the content of the best Microorganism Technology formula, which is named RIM (Refresh Microorganism). The results of this RIM formulation were then tested in sugarcane bud chip nurseries in the Laboratory and sugarcane nurseries at the Green House. The process of sugarcane bud chip seeding was continued at the Green House with a combination treatment of RIM with manure. The results of the analysis of variance showed that the application of RIM, manure and control on sugarcane bud chips had no significant effect on shoot growth time (Table 1) but had a significant effect on the percentage of shoot growth (Table 2). Observation of the percentage of shoots growing stated that the addition of RIM resulted in a diversity in the percentage of bud chip that grew where the treatments of S2, S3, S4, S5, S6 and S7 were significantly different from the percentage of shoots growing in the $\mathrm{SO}$ treatment (Control).

\section{Plant height}

The results of the analysis of variance showed that giving RIM had a significant effect on the height of the sugarcane bud chip. At the age of 50 DAP, the height of the bud chip plants in S0 (control) treatment was significantly different from the S1 treatment and S2, S3, S4, S5, S6 and S7 treatments. However, at the age of 30 and 40 DAP there was no significant difference between these treatments. The provision of manure and RIM showed a significant difference compared to control. At the age of 70 HST, giving RIM alone or giving manure alone was not significantly different from Control. The combination of RIM and manure contributed significantly to the increase in plant height (Table 3). 


\section{Number of leaves}

The results of the analysis of variety showed that the application of RIM and manure had no significant effect on the number of sugarcane bud chip leaves at the age of 30 and 40 DAP, but at the age of 50,60 and 70 DAP there was a significant difference. Based on the results of observations made at the age of $\mathbf{5 0}$ to $\mathbf{7 0}$ days afterwards, the number of bud chip leaves in each treatment had a significantly different value (Table 4). The effect of giving RIM alone or simultaneously with manure can increase the number of leaves.

\section{Plant nutrient elements}

Content of Nitrogen and Potassium. The content of $\mathrm{N}$ and $\mathrm{K}$ elements in this study increased the provision of RIM and manure (S1, S2, S3, S4, S5, S5, S6 and S7, analysis of various $\mathrm{K}$ content had a significant effect compared to control (S0) between these treatments. increase the content of Nitrogen and Potassium in sugarcane seeds at the end of this research 70 days after planting. Potassium different from the control this difference can be seen in Figure 5.

Contents of $\mathbf{P}$, calcium, magnesium and $\mathbf{p H}$. The elemental content of phosphorus, calcium, magnesium increases with the provision of RIM and manure. This can be seen from the increase in elements of P, Ca, Mg S1, S2, S3, S4, S5, S6 and $\mathrm{S} 7$ compared to SO treatment (control). The highest P content was obtained in the S3 treatment (giving RIM $20 \mathrm{gr} / \mathrm{It}$ ), but it was not significantly different from the S2, S5 and S6 treatments (giving RIM and manure). Calcium content in S3 treatment (giving RIM $20 \mathrm{gr} / \mathrm{It}$ ) was not significantly different from the treatment with RIM and manure (S4 and S5). The difference in the treatment of giving RIM $10 \mathrm{gr} /$ Itd of manure alone does not provide a significant difference in the calcium content, which can be seen in Figure 6. Meanwhile, the phosphorus content of sugarcane seeds up to 70 days after planting was relatively different in the treatment given by RIM, a combination of RIM and manure and manure alone compared to the control. However, the $\mathrm{pH}$ was not different in all treatments, there was no significant difference.

Table 1 - The effect of giving RIM various doses and combinations of manure application on sugarcane bud chip growing time.

\begin{tabular}{lc} 
Treatment & Shoots growth time (days) \\
\hline S0 (Control) & 6.75 \\
S1 (RIM 5 g) & 7.50 \\
S2 (RIM 10 g) & 8.50 \\
S3 (RIM 20 g) & 8.75 \\
S4 (RIM 5 g + manure ) & 7.25 \\
S5 (RIM 10 g + manure ) & 8.50 \\
S6 (RIM 20 g + manure ) & 8.90 \\
S7 (manure) & 7.80 \\
BNT5\% & NR (No Response)
\end{tabular}

Table 2 - Effect of RIM on various doses and combinations of manure application on the percentage of buds growing sugar cane chips.

\begin{tabular}{lc} 
Treatment & Percentage of shoots (\%) \\
\hline S0 (control) & $53.75 \mathrm{a}$ \\
S1 (RIM 5 g) & $67.50 \mathrm{~b}$ \\
S2 (RIM 10 g) & $71.50 \mathrm{bc}$ \\
S3 (RIM 20 g) & $76.75 \mathrm{bc}$ \\
S4 (RIM 5 g + manure ) & $77.25 \mathrm{c}$ \\
S5 (RIM $10 \mathrm{~g}+$ manure ) & $78.50^{\mathrm{c}}$ \\
S6 (RIM $20 \mathrm{~g}+$ manure ) & $86.90 \mathrm{~d}$ \\
S7 (manure) & $68.70^{\mathrm{b}}$ \\
\hline *Note: Figures accompanied by the same letter are not significantly different based on the LSD test at the 5\% level
\end{tabular}

Table 3 - Effect of RIM on various doses and combinations of manure application on sugarcane bud chip plant height.

\begin{tabular}{|c|c|c|c|c|c|}
\hline \multirow[b]{2}{*}{ Treatment } & \multirow{2}{*}{ Plant Height (cm) } & \multicolumn{4}{|c|}{ Shoots Growth Time (days) } \\
\hline & & 40 & 50 & 60 & 70 \\
\hline SO (control) & 9.36 & 10.56 & 11.79 a & 13.25 a & 15.33 a \\
\hline S1 (RIM 5 g) & 9.58 & 11.32 & 13.55 b & $14.88^{b}$ & 15.88 a \\
\hline S2 (RIM 10 g) & 9.63 & 11.39 & $13.89 \mathrm{~b}$ & $14.78^{b}$ & 16.22 b \\
\hline S3 (RIM 20 g) & 9.78 & 11.45 & $14.55 \mathrm{bc}$ & $15.36 \mathrm{bc}$ & $16.59 \mathrm{~b}$ \\
\hline S4 (RIM $5 \mathrm{~g}+$ manure ) & 9.65 & 11.36 & $13.78 b c$ & $14.99 b c$ & $16.55^{b}$ \\
\hline S5 (RIM 10 g + manure ) & 9.77 & 11.79 & $15.44 \mathrm{~cd}$ & $15.89 \mathrm{c}$ & $16.52 \mathrm{~b}$ \\
\hline S6 (RIM 20 g + manure ) & 9.82 & 11.89 & $15.88^{d}$ & $15.99 \mathrm{c}$ & $17.22 \mathrm{c}$ \\
\hline S7 (manure) & 9.52 & 11.22 & 13.77 & $14.33^{b}$ & 15.89 a \\
\hline BNT 5\% & $\mathrm{Nr}$ & $\mathrm{Nr}$ & 1.5 & 0.8 & 0.7 \\
\hline
\end{tabular}


Table 4 - Effect of RIM on various doses and combinations of manure application on the number of leaves of sugarcane bud chips

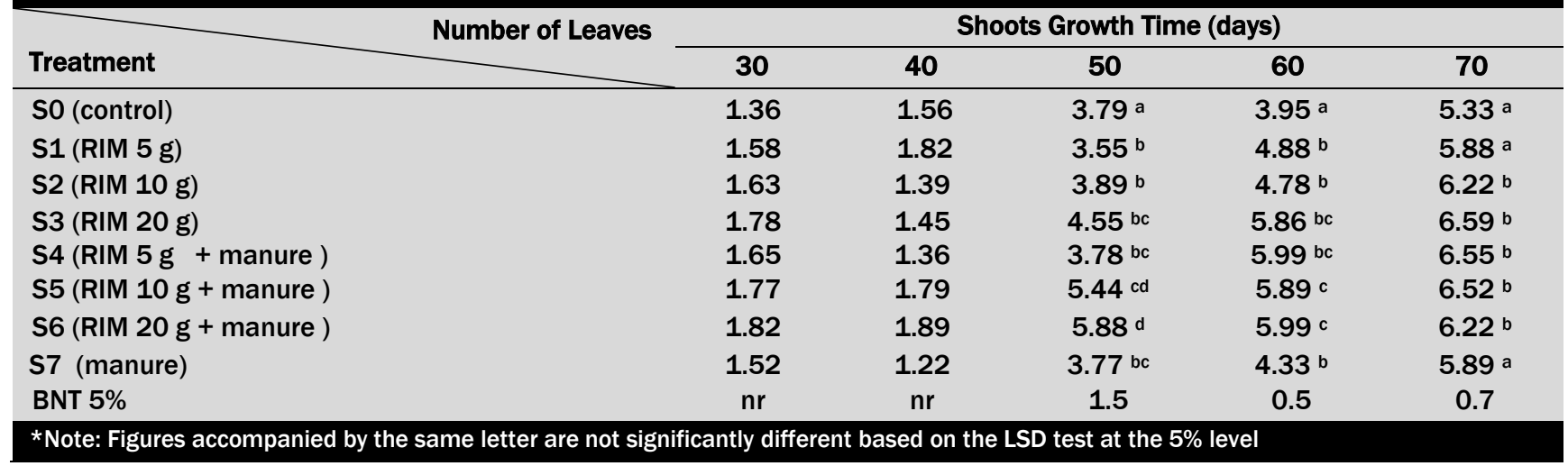

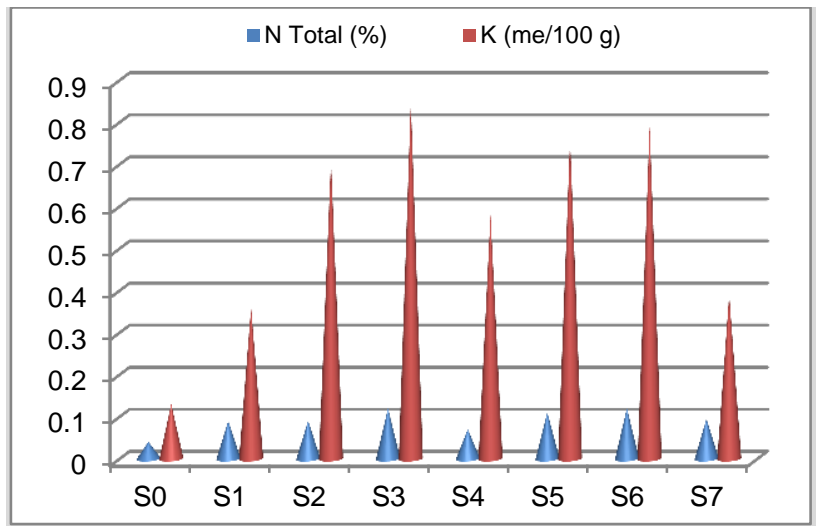

Figure 5 - Nitrogen and potassium nutrient content in sugarcane bud chip seeding research.

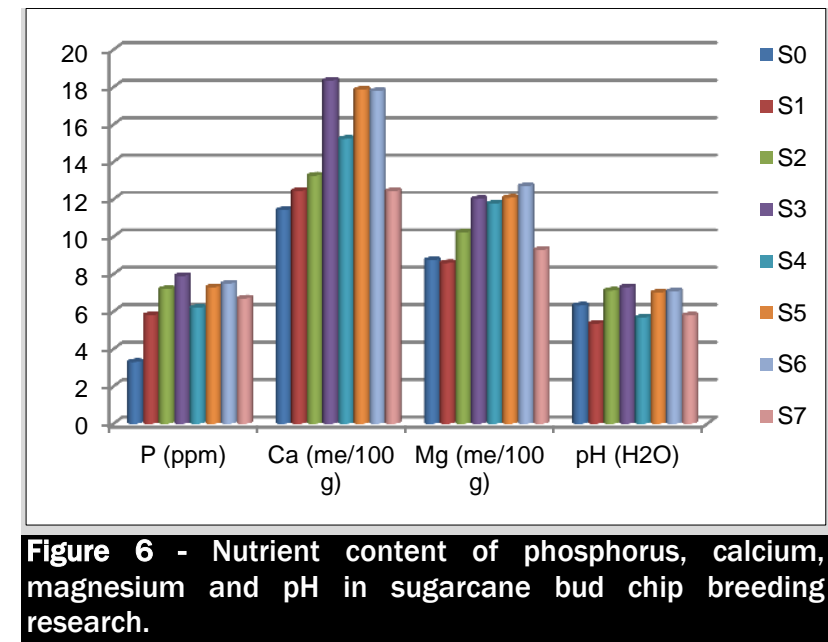

\section{DISCUSSION}

The results showed that from the time of growth the treatments given by RIM and the provision of manure and the combination (S0, S1, S2, S3, S4, S5, S6 and S7) were not significantly different from the control (S0). However, the parameters of the proportion of plant proportions, plant height and number of plants treated with SO (control) were significantly different from other treatments and the lowest treatment was at certain observation ages.

This is because in the SO treatment (control) there was no colony of RIM bacteria which was able to increase plant growth from hormones and some organic compounds produced by these bacteria (Hindersah et al., 2004; McMillan, 2007). In addition to hormones and organic compounds, RIM can increase resistance to pathogen attack, for example Colletotrichum falcatum (Rahni, 2012), one way for RIM bacteria to increase plant resistance to pathogenic attack is by producing secondary metabolites such as siderophore. antibiotics, hydrogen cyanide, extracellular enzymes and induce plant resistance and are able to synthesize pathogenic cell wall degradation enzymes such as chitination, 1,3-glucanase, 1,4-glucanase, cellulase, lipase and protease and produce 1-aminocyclopropane, ACC deaminase (Baharun et al., 2003; Haung et al., 2004; Sutariati, 2006).

The results showed that the growth of bud chips with SO treatment (control) was lower than that of other treatments (S1, S2, S3, S4, S5, S6 and S7) for certain parameters and age of observation. Giving RIM and manure could increase the percentage of shoot growth and plant height compared to the control. Observation data from several parameters that represent the growth of bud chip treatment $\mathrm{SO}$ (control) is the observation data of bud chip plant height parameters where the S0 treatment (control) at the age of 70 DAS is almost equivalent to all treatments given RIM at the age of 60 DAP. This means that the growth of bud chip with SO treatment (control) is slower than other treatments. This is in accordance with the results of research that the use of bacteria can increase growth compared to control treatment (Syamsuddin and Ulim, 2013). According to Suwahyono et al. (2011), the microbes contained in biological fertilizers when applied to plants can bind nitrogen from the air, dissolve phosphates that are bound in the soil and break down complex organic compounds into simpler compounds and stimulate plant growth.

Trichoderma, Sacharomyces, Bacillus, Rhizobium, Azotobacter and Pseudomonas found in the RIM formulation can be consortium and work together to increase the acceleration of growth of shoots from clear sugarcane. Especially, if it is mixed with manure which is food for these bacteria, Suwahyono et al. (2011) stated that the combination treatment of $\mathrm{N}$, $\mathrm{P}$ and $\mathrm{K}$ fertilizers as well as biological fertilizers produced a larger stem diameter compared to the single biological fertilizer treatment. 


\section{CONCLUSION}

Its concluded that the use of RIM's biological agents (such as refresh microorganisms) using Tricho derma, Sacharomyces, Bacillus, Rhizobium, Azotobacter and Pseudomonas bacteria can increase the growth of sugarcane buds. The combination of using RIM and manure can increase the number of leaves and the percentage of growth of sugarcane bud chips. It is necessary to continue research in the field in order to know the production and yield.

\section{DECLARATIONS}

\section{Consent to publish \\ Not applicable.}

\section{Competing interests}

The authors declare that they have no competing interests.

\section{Authors' Contribution}

All the three authors reviewed the paper and contributed in developing the content.

\section{REFERENCES}

Agricultural Statistics at a Glance (2018). Ministry of Agriculture \& Farmers Welfare Department of Agriculture, Cooperation \& Farmers Welfare, Directorate of Economics and Statistics, New Delhi. Link

Baharum SN, Salleh AB, Razak CN, Basri M, Rahman MB and Rahman RN (2003). Organic solvent tolerant lipase by Pseudomonas sp. strain S5: stability of enzyme in organic solvent and physical factors effecting its production. Annals of Microbiology, 53(1):75-84. Link I Google Scholar

Ferreira T, Tsunada MS, Bassi D, Araújo P, Mattiello L, Guidelli GV, Righetto GL, Gonçalves VR, Lakshmanan P and Menossi M (2017), Sugarcane water stress tolerance mechanisms and its implications on developing biotechnology solutions. Frontiers in Plant Science, 8: 1077. Google Scholar I Doi: https://doi.org/10.3389/fpls.2017.01077

Hindersah R and Simarmata T. (2004) Potensi rizobakteri Azotobacter dalam meningkatkan kesehatan tanah. Jurnal Natur Indonesia, 5(2): 127-133. Google scholar: Google Scholar

Huang CJ and Chen CY (2004). Gene cloning and biochemical characterization of chitinase CH from Bacillus cereus 28-9. Annals of microbiology, 54: 289-298. Google Scholar I Link

McMillan S (2007). Promoting growth with PGPR. The Canadian Organic Grower. Soil Foodweb Canada Ltd. Soil Biology Lab. \& Learning Centre, 2007: 3-4. Google Scholar I Link

Rampazzo PE, Marcos FC, Cipriano MA, Marchiori PE, Freitas SS, Machado EC, Nascimento LC, Brocchi M, Ribeiro RV (2018). Rhizobacteria improve sugarcane growth and photosynthesis under well-watered conditions. Annals of Applied Biology, 172(3): 309320. Google Scholar I Doi: https://doi.org/10.1111/aab.12421

Sutanto R (2002). Application of organic farming, towards sustainable agriculture and alternative, Yogyakarta, Canisius.

Sutariati GA (2006). Perlakuan benih dengan agens biokontrol untuk pengendalian penyakit antraknosa, peningkatan hasil dan mutu benih cabai [Disertasi]. Bogor (ID): Institut Pertanian Bogor. Google scholar

Suwahyono U (2011). Petunujk Praktis Penggunaan Pupuk Organik Secara Efektif \& Efisien. Penebar Swadaya Grup, Jakarta. ISSN: 978 979-002-476-2. Google Scholar

Syamsuddin S and Ulim MA (2013). Daya hambat rizobakteri kandidat agens biokontrol terhadap pertumbuhan koloni patogen phytophthora capsici secara in vitro. Jurnal Floratek, 8(2): 64-72. Google Scholar I Link

Thierfelder C, Baudron F, Setimela P, Nyagumbo I, Mupangwa W, Mhlanga B, Lee N and Gérard B (2018). Complementary practices supporting conservation agriculture in southern Africa. A review. Agronomy for Sustainable Development, 38: 16. Google Scholar DOI: https://doi.org/10.1007/s13593-018-0492-8 